\title{
Tata Kelola Panen dan Pengangkutan Menentukan Hasil Tandan Kelapa Sawit di Kebun Adolina, Sumatera Utara
}

\section{Harvesting Management and Determine the Yield of Oil Palm Bunch Product Transportation at Adolina Plantation, North Sumatera}

\author{
Imam Fauzi Tanjung dan Edi Santosa* \\ Departemen Agronomi dan Hortikultura, Fakultas Pertanian, Institut Pertanian Bogor \\ (Bogor Agricultural University), Jl. Meranti, Kampus IPB Darmaga, Bogor 16680, Indonesia \\ Telp. \& Faks.62-251-8629353 e-mail agrohort@apps.ipb.ac.id \\ *Penulis Korespondensi : edisang @ gmail.com
}

Disetujui : 21 Mei 2018 / Published Online September 2019

\begin{abstract}
Proper harvesting methods is important to obtain high yield of oil extract with low levels of free fatty acids content. Observation on harvesting management was held at Adolina Plantation, Sumatera Utara on February $5^{\text {th }} 2018$ until June $30^{\text {th }} 2018$ consisted of harvest organization, harvesting skill, monitoring and evaluation. Transportation efficiency was observed by comparing the technical and load time of fruits. Results showed that harvest rotation, estimation and realization of harvest density, number of workers, criteria for mature harvest experienced adjustments from standard listed in standard operating procedure (SOP). Such deviation from SOP was due to company strategy to reduce yield loss by theft. In this plantation all mature fruits were succesfully harvested after the company adjusted new harvesting cycle, although there was a technical problem faced by harvester to comply to harvesting standard on both planting oil palm trees using common and big hole system. Transport efficiency showed different technical difficulties and time requirement between bunch loading using and without bridge.
\end{abstract}

Keywords: adjustment, hanca, hole, transportation.

\begin{abstract}
ABSTRAK
Pemanenan perlu dilakukan dengan baik untuk mendapatkan rendemen minyak yang tinggi dengan kadar asam lemak bebas yang rendah. Pengamatan terhadap manajemen panen dilaksanakan di Kebun Adolina, Sumatera Utara pada tanggal 5 Februari 2018 sampai 30 Juni 2018terdiri organisasi panen, perencanaan panen, pelaksanaan panen, pengawasan dan evaluasi panen. Secara khusus efisensi pengangkutan diamati dengan membandingkan teknis dan waktu muat buah pada hanca. Hasil pengamatan terkait manajemen panen seperti rotasi panen, estimasi dan realisasi dari angka kerapatan panen, jumlah tenaga kerja, kriteria matang panen mengalami deviasi dari standar prosedur operasional (SPO) perusahaan. Hal ini dilakukan untuk mencapai target produksi bulanan saat kerapatan buah menurun akibat pencurian. Di kebun tidak ditemukan adanya losses berupa buah matang tidak dipanen setelah ada perubahan sistem hanca. Selain itu terdapat perbedaan tingkat kepatuhan pemanen pada tanaman yang menggunakan sistem tanam standar dan big hole. Hasil pengamatan terkait efisiensi pengangkutan menunjukkan adanya perbedaan teknis dan waktu yang nyata antara cara pengangkutan menggunakan jembatan atau tidak.
\end{abstract}

Kata kunci: hanca, hole, pengangkutan, penyesuaian. 


\section{PENDAHULUAN}

Komoditas perkebunan yang menjadi primadona saat ini adalah kelapa sawit (Elaeis guineensis Jacq). Berdasarkan pengusahaannya, luas areal perkebunan kelapa sawit terus meningkat setiap tahunnya, yakni pada tahun 2014-2015 dari 10754801 ha menjadi 11260 277 ha. Hal ini mengantarkan Indonesia menjadi produsen crude palm oil (CPO) terbesar di dunia dengan produksi 31070015 ton tahun ${ }^{-1}$ dan menghasilkan nilai ekspor sebesar Rp15 385275000.00 US\$ (Ditjenbun, 2016). Perkebunan kelapa sawit juga memberikan keuntungan dalam menyediakan lapangan pekerjaan bagi masyarakat (Sipayung, 2012).

Kelapa sawit merupakan salah satu tanaman penghasil minyak nabati paling tinggi dibandingkan tanaman penghasil minyak lainnya jika dilihat berdasarkan produktivitas minyak ton ha $^{-1} \operatorname{tahun}^{-1}$ (PASPI, 2017). Produk utama dari kelapa sawit adalah tandan buah segar (TBS) yang kemudian diolah menjadi crude palm oil (CPO) dan palm kernel oil (PKO). Keduanya merupakan minyak mentah yang digunakan sebagai bahan baku untuk berbagai produk olahan.

Salah satu aspek penting pada budidaya kelapa sawit adalah pemanenan. Pemanenan memiliki peranan penting dalam menjaga kuantitas (rendemen) dan kualitas minyak asam lemak bebas (ALB) saat proses ekstraksi TBS. Rendemen dan kadar ALB dapat diatur melalui fraksi matang panen. Semakin matang buah menyebabkan rendemen minyak tinggi tetapi mutu minyak menjadi rendah karena meningkatnya kadar ALB (Sulistyo et al., 2010). Pahan (2008) juga menyampaikan bahwa rendemen dapat ditingkatkan melalui pemanenan buah sesuai kriteria matang panen, sedangkan kadar ALB dapat diturunkan melalui pengangkutan hasil tepat waktu. Kandungan ALB tidak nyata dipengaruhi oleh curah hujan, tetapi ditentukan oleh jumlah buah restan dimana setiap kenaikan 1\% akan meningkatkan ALB sebesar 0.001\% (Purwanto dan Santosa, 2016). Salah satu syarat mutu yang harus dipenuhi perusahaan saat melakukan ekspor adalah minyak dengan kadar ALB maksimum 5\% (Sibuea, 2014). Kadar ALB yang tinggi dapat menurunkan kualitas yang menyebabkan minyak berbau tengik. Kondisi turunnya kualitas minyak mengakibatkan penurunan harga minyak (Pahan, 2008). Saat proses panen, TBS yang baru dipotong sudah memiliki kadar ALB sekitar 2\% (Pahan, 2008). ALB akan terus meningkat sebesar $0.9-1.0 \%$ setiap 24 jam sehingga semakin cepat diolah maka akan semakin baik (Sibuea, 2014). Pengolahan melalui perebusan TBS dipabrik menggunakan suhu tertentu dapat menurunkan laju peningkatan kadar ALB (Anarki, 2012). Oleh sebab itu perusahaan tidak dapat hanya mementingkan rendemen saja tetapi juga harus menjaga persyaratan mutu melalui manajemen panen. Kegiatan harus diperhatikan mulai dari saat pemotongan TBS, pengangkutan hingga pengolahan pabrik karena setiap proses dapat menurunkan kuantitas dan kualitas minyak (Pardamean, 2012). Tujuan penelitian ini adalah adalah memahami secara teknis dan manajerial pemanenan dan mengamati efisiensi pengangkutan tandan kelapa sawit di Kebun Adolina, Sumatera Utara.

\section{BAHAN DAN METODE}

Penelitian dilaksanakan pada tanggal 5 Februari 2018 sampai 30 Juni 2018 di Kebun Adolina, Sumatera Utara. Pengamatan pada kegiatan magang diarahkan untuk mendapatkan data primer dan data sekunder. Data primer didapatkan melalui pengamatan langsung, disksusi dan wawancara dengan karyawan, mandor, asisten afdeling dan asisten kepala. Pengamatan data primer yang diamati dari aspek panen di Kebun Adolina adalah :

1. Organisasi Panen. Pengamatan yang dilakukan mengenai struktur, tanggung jawab dan wewenang mengevaluasi hasil panen di kebun. Data diperoleh melalui kegiatan wawancara dan diskusi kepada setiap tingkatan pengelola panen yang terlibat.

2. Perencanaan Panen. Pengamatan yang dilakukan mengenai kegiatan yang dipersiapkan sebelum terlaksananya panen yaitu rotasi panen, kapveld panen, angka kerapatan panen (AKP), tenaga kerja dan hanca panen. Data diperoleh melalui pengamatan langsung dan diskusi kepada mandor dan krani produksi.

a. Rotasi. Pengamatan yang dilakukan adalah ketepatan perpindahan hanca panen, rotasi panen terpendek dan terpanjang satu blok menuju blok tersebut saat bulan Mei dan Juni.

b. Kapveld. Pengamatan yang dilakukan adalah pembagian areal per semester dan ketepatan penggunaan kapveld.

c. Angka Kerapatan Panen (AKP). Pengamatan dilakukan dengan cara menghitung angka kerapatan tiap kapveld panen selama 5 hari untuk 5 kapveld. Setiap kapveld diambil 3 blok dan setiap blok diamati $5 \%$ dari jumlah pokok. 
Kemudian dibandingkan antara estimasi dan realisasi produksi.

d. Kebutuhan Tenaga Kerja. Pengamatan yang dilakukan adalah menghitung jumlah tenaga kerja yang hadir dan membandingkan dengan rencana tenaga kerja yang dibutuhkan berdasarkan angka kerapatan panen selama 5 hari kerja.

e. Hanca Panen. Pengamatan dilakukan mengenai hanca yang digunakan, alasan dan dampak dari penggunaan hanca selama bulan Mei dan Juni.

3. Pelaksanaan Panen. Pengamatan dilakukan mengenai pelaksanaan kegiatan panen oleh pemanen mulai dari perlengkapan panen, kriteria matang panen, teknis panen dan pengangkutan hasil. Data diperoleh melalui pengamatan langsung dan diskusi dengan pemanen, pemuat dan supir.

a. Perlengkapan Panen. Pengamatan yang dilakukan adalah kepatuhan penggunaan alat pelindung diri dan alat panen oleh pemanen

b. Kriteria Matang Panen. Pengamatan yang dilakukan adalah mengamati jumlah brondolan dipiringan yang menjadi kriteria matang panen realisasi 6 orang pemenanen saat tanggal 10-15 dan 25-30 pada tahun tanam 2008. Data diambil dari 10 potongan buah pemanen dan dibandingkan dengan SOP maupun pustaka terkait.

c. Teknis Panen. Pengamatan yang dilakukan adalah mengamati proses pemanenan sejak kumpulan pagi, pemotongan buah hingga penyusunan hasil ditempat pengumpulan hasil.

d. Pengangkutan Hasil. Pengamatan yang dilakukan adalah mengamati proses dan waktu yang dibutuhkan untuk muat, bongkar muatan, keberangkatan dan kepulangan dari 3 truk selama 3 hari pengangkutan tandan buah segar (TBS). Pengamatan juga dilakukan dengan membandingkan waktu muat buah seluruh tempat penerimaan hasil (TPH) antara penggunaan jembatan dan tidak pada 1 trip pengangkutan.

4. Pengawasan dan Evaluasi Panen. Pengamatan dilakukan saat telah terlaksananya panen terdiri dari pengawasan mutu, denda dan sanksi panen, kapasitas pemanen, basis dan premi panen serta losses yang terjadi. Data diperoleh melalui pengamatan langsung, diskusi dan mewawancari seluruh tenaga kerja yang terlibat dalam proses panen. a. Pengawasan Mutu. Pengamatan yang dilakukan adalah mengamati mutu hanca dan mutu tempat pengumpulan (hasil) terhadap 5 pemanen dalam satu blok sebanyak 3 ulangan pada tahun tanam 2008. Mutu hanca yang diamati yaitu buah tinggal, brondolan tidak dikutip, pelepah sengkleh atau tidak dipotong dari 10 tanaman yang dipanen oleh setiap pemanen dari 2 lorong. Mutu TPH yang diamati yaitu kematangan buah dan potongan tandan dari keseluruhan TPH setiap pemanen. Selain itu juga diamati perbedaan mutu hanca dengan cara yang sama dari tanaman dengan lubang tanam standar dan lubang tanam big hole.

b. Denda dan Sanksi Panen. Pengamatan yang dilakukan adalah sistem dan penerapan dari setiap kesalahan yang dilakukan pemanen.

c. Kapasitas Pemanen. Pengamatan yang dilakukan adalah mengamati kapasitas yang diperoleh 3 pemanen yang menggunakan kernet dan 3 pemanen yang tidak menggunakan selama 5 hari berurutan.

d. Basis dan Premi Panen. Pengamatan yang dilakukan adalah sistem dan penerapan basis dan premi yang diterima berdasarkan kapasitas yang dimiliki pemanen.

e. Kehilangan Hasil. Pengamatan yang dilakukan adalah sistem keamanan dan penyebab kehilangan buah yang disebabkan pencurian.

Data sekunder didapatkan dari studi literatur dan laporan manajemen kebun berupa letak geografis, wilayah administratif, tata guna lahan, peta kebun, keadaan tanah, keadaan iklim 5 tahun, data produksi, struktur organisasi dan aturan serta norma kerja perusahaan.

Analisis data dilakukan secara deskriptif dan kuantitatif dengan membandingkan data yang diperoleh dengan standar perusahaan dan literatur. Data kuantitatif berupa rata-rata, persentase hasil dan uji t-student kemudian disajikan dalam bentuk narasi, tabel dan diagaram sesuai kebutuhan.

\section{HASIL DAN PEMBAHASAN}

\section{Pemanenan}

Pemanenan merupakan serangkaian kegiatan yang dimulai dari menurunkan serta menyusun pelepah, menurunkan TBS, mengutip brondolan dan membawa TBS ke TPH untuk segera diangkut ke pabrik. Kegiatan panen 
bertujuan untuk memaksimalkan dan menjaga potensi hasil yang ada dilapangan. Potensi tersebut tidak hanya dilihat dari total produksi TBS harian dilapangan, melainkan total rendemen yang dapat dihasilkan dari proses ekstraksi TBS di pabrik. Proses pemanenan harus berlangsung secara konsisten, maka dari itu harus memperhatikan beberapa hal terkait pengelolaan panen yaitu organisasi panen, perencanaan panen, pelaksanaan panen, pengawasan panen dan evaluasi panen.

\section{Organisasi Panen}

Organisasi panen merupakan sistem yang mengatur semua pihak yang terlibat dalam kegiatan panen. Organisasi panen terdiri dari pemanen, petugas muat, supir, mandor panen, krani produksi, krani I, mandor I, asisten afdeling, askep dan manajer. Melalui organisasi panen dapat diketahui struktur dan tanggung jawab setiap tingkatan yang ada. Dalam hal teknis merupakan tanggung jawab pemanen, pemuat dan supir. Pemanen bertanggung jawab menjaga mutu hanca dan TPH sesuai standar prosedur operasional (SPO) agar kualitas rendemen terjaga, sedangkan pemuat dan supir bertanggung jawab mengantarkan buah yang sesuai kriteria tepat waktu ke pabrik kelapa sawit (PKS) untuk menjaga kadar ALB. Dalam hal perencanaan, pengawasan dan administrasi merupakan tanggung jawab dari mandor panen, krani produksi, krani I mandor I, asisten afdeling dan asisten kepala (askep). Pengawasan dilakukan secara bertingkat dan sesuai proporsi. Mandor panen sepenuhnya mengawasi setiap mandoran karyawan, mandor I mengawasi seluruh kemandoran, asisten mengawasi mandor I dan seluruh kemandoran di afdeling dan askep mengawasi asisten afdeling dan seluruh kemandoran yang ada di rayon. Askep merupakan perpanjangan tangan manajer dari setiap rayon. Proses panen sepenuhnya menjadi tanggung jawab manajer untuk menjaga kualitas dan kuantitas minyak yang akan dihasilkan secara konsisten. Manajer selain dibantu askep juga dibantu petugas pemeriksa buah (P2B) afdeling yang berada dibawah asisten afdeling dan bertugas melakukan sortasi sesuai kriteria sebelum TBS diangkut. Manajer juga harus melakukan evaluasi panen berdasarkan laporan mutu buah di loading ramp sebagai bentuk pengecekan ulang atas pelaksanaan panen afdeling.

\section{Perencanaan Panen}

Perencanaan panen atau biasanya disebut sebagai pengaturan panen merupakan tahapan yang dipersiapkan sebelum terlaksananya kegiatan panen. Panen umumnya dipersiapkan satu hari sebelum pelaksanaan, meskipun ada juga sistem panen yang telah dipersiapkan sejak awal memasuki TM seperti rotasi dan kapveld panen. Hal-hal yang diperhatikan saat perencanaan adalah angka kerapatan panen, tenaga kerja, dan sistem hanca panen yang digunakan.

\section{Rotasi Panen}

Rotasi atau pusingan adalah jarak waktu antara panen pertama sampai panen berikutnya dalam blok yang sama. Rotasi panen sangat ditentukan oleh berbagai faktor seperti jumlah hari, jumlah tenaga kerja, kerapatan buah, kapasitas pemanen dan iklim per semester. Kebun Adolina menerapkan rotasi panen yang berbeda antara semester I dan semester II. Rotasi panen yang diterapkan pada semester I adalah 5/7, artinya panen dilaksanakan selama 5 hari dalam seminggu.

Tabel 1. Realisasi rotasi panen semester I afdeling IV

\begin{tabular}{|c|c|c|c|c|c|c|c|c|}
\hline \multirow{2}{*}{ Bulan } & \multirow{2}{*}{$\begin{array}{c}\text { Minggu } \\
\mathrm{Ke}\end{array}$} & \multicolumn{7}{|c|}{ Hari } \\
\hline & & Senin & Selasa & Rabu & Kamis & Jumat & Sabtu & Minggu \\
\hline \multirow{5}{*}{ Mei } & 1 & & & $\mathrm{~K} 4,5$ & K1 & K2 & $\mathrm{K} 3,4$ & \\
\hline & 2 & $\mathrm{~K} 4,5$ & K5,1 & $\mathrm{K} 2,3$ & $\mathrm{~K} 3,4$ & $\mathrm{~K} 4,5$ & $\mathrm{~K} 1,2$ & $\mathrm{~K} 2,3$ \\
\hline & 3 & $\mathrm{~K} 3,4$ & K5,1 & $\mathrm{K} 1,2,3$ & $\mathrm{~K} 3,4$, & K5,1 & $\mathrm{K} 2,3$ & $\mathrm{~K} 3,4$ \\
\hline & 4 & $\mathrm{~K} 4,5$ & K5,1 & $\mathrm{K} 1,2$ & $\mathrm{~K} 2,3$ & $\mathrm{~K} 3,4$ & $\mathrm{~K} 4,5$ & $\mathrm{~K} 5,1$ \\
\hline & 5 & $\mathrm{~K} 1,2$ & K2,3 & K3,4 & $\mathrm{K} 4,5$ & & & \\
\hline \multirow{5}{*}{ Juni } & 1 & & & & & $\mathrm{~K} 1,2$ & $\mathrm{~K} 2,3$ & $\mathrm{~K} 3,4$ \\
\hline & 2 & $\mathrm{~K} 4,5$ & $\mathrm{~K} 1,2$ & $\mathrm{~K} 2,3$ & $\mathrm{~K} 4,5$ & K5,1 & $\mathrm{K} 2,3$ & $\mathrm{~K} 3,4$ \\
\hline & 3 & $\mathrm{~K} 4,5$ & K5,1 & $\mathrm{K} 1,2$ & & & & \\
\hline & 4 & K3 & $\mathrm{K} 3,4$ & $\mathrm{~K} 4,5$ & K5,1 & $\mathrm{K} 1,2$ & $\mathrm{~K} 2,3$ & K3 \\
\hline & 5 & K4 & $\mathrm{K} 4,5$ & K5 & $\mathrm{K} 1$ & $\mathrm{~K} 1,2$ & $\mathrm{~K} 3$ & \\
\hline
\end{tabular}

Keterangan :

Hari libur kalender, : Hari libur pengganti Rotasi terpendek, : Rotasi terpanjang 
Bul. Agrohorti 7(3): 351-361 (2019)

Tabel 2. Angka kerapatan per kapveld panen afdeling IV

\begin{tabular}{|c|c|c|c|c|c|}
\hline Kapveld & Jumlah pokok & $\begin{array}{l}\text { Estimasi } \\
\text { Produksi (kg) }\end{array}$ & $\begin{array}{l}\text { Realisasi } \\
\text { produksi (kg) }\end{array}$ & $\begin{array}{c}\% \text { realisasi } \\
\text { terhadap } \\
\text { estimasi }\end{array}$ & P-Value \\
\hline $\mathrm{I}$ & 7219 & 10595 & 10611 & 100.15 & $0.997^{\mathrm{tn}}$ \\
\hline II & 9378 & 11730 & 12510 & 106.6 & $0.833^{\text {tn }}$ \\
\hline III & 5450 & 9177 & 9171 & 99.93 & $0.999^{\operatorname{tn}}$ \\
\hline IV & 8385 & 15435 & 15641 & 101.33 & $0.979^{\operatorname{tn}}$ \\
\hline V & 6698 & 7500 & 7980 & 106.4 & $0.750^{\operatorname{tn}}$ \\
\hline
\end{tabular}

Keterangan : $(\operatorname{tn})=$ tidak berbeda nyata pada taraf $\alpha=5 \%$.

Sedangkan semester II rotasi yang diterapkan adalah 6/7, artinya panen dilaksanakan selama 6 hari dalam seminggu (PTPN IV, 2007). Hasil pengamatan rotasi panen dapat dilihat pada Tabel 1 .

Berdasarkan data pada Tabel 1 terlihat realisasi yang berlangsung belum sesuai SPO yang ditetapkan perusahaan. Pemanenan yang direncanakan selama 5 hari kerja dalam seminggu tetapi ditemukan pelaksanaannya selama 7 hari kerja, sehingga akan kembali ke hanca yang sama minimal setelah 5 hari kerja. Pemanenan selama 7 hari kerja disebabkan rencana kerja anggaran perusahaan (RKAP) tahunan yang telah disebar kedalam target bulanan tidak akan terpenuhi apabila pemanenan dilakukan selama 5 hari kerja. Hal ini disebabkan angka kerapatan buah menurun drastis akibat pencurian TBS dan berat rata-rata tandan menurun akibat serangan hama ulat kantong.

Ulat pemakan daun mengakibatkan penurunan produksi hingga $30-40 \%$ setelah 2 tahun dari berkurangnya daun sebanyak $50 \%$ (Sulistyo et al., 2010)

\section{Angka Kerapatan Panen (AKP)}

AKP adalah nilai yang dihitung untuk menduga sebaran buah matang yang dapat dipanen pada suatu blok. Perhitungan AKP memiliki manfaat dalam mengestimasi produksi dan merencanakan jumlah tenaga kerja serta pengangkutan yang dibutuhkan. Selain itu AKP juga bermanfaat untuk menyesuaikan jumlah blok yang dipanen berdasarkan hasil estimasi dan target produksi harian. Perhitungan AKP dilakukan oleh mandor panen saat 1 hari sebelum panen dan biasanya dilakukan sore hari setelah pengawasan (jam dinas) selesai. Berdasarkan SE direktur produksi, perhitungan AKP dilakukan dengan mengambil sampel tanaman sebanyak 5\% dari populasi total dalam 1 blok. Daftar angka kerapatan panen afdeling IV dapat dilihat pada Tabel 2.

Data pada Tabel 2 menunjukkan bahwa \% realisasi terhadap estimasi tiap kapveld setelah dibandingkan dengan standar perusahan sebesar $100 \%$ tidak berbeda nyata. Setiap kapveld diambil sampel sebanyak 3 blok. Perusahaan juga memberikan toleransi sebesar $\pm 5 \%$, artinya $\%$ realisasi terhadap estimasi pada kapveld II dan V berada sedikit diatas batas ambang. Berdasarkan data diatas, pengamatan juga dilakukan dengan mengidentifikasi estimasi dan realisasi hanca yang dikategorikan rawan pada setiap kapveld. Hasilnya menunjukkan bahwa realisasi produksi pada hanca rawan menunjukkan angka yang lebih besar dibandingkan estimasi. Hal ini disebabkan adanya kebijakan penurunan kriteria matang panen, sehingga pemanen diduga memotong buah selain buah yang dikategorikan buah matang normal. Menurut Pardamean (2012) kriteria matang panen dapat disesuaikan dengan kondisi setempat. Khusus areal rawan pencurian, kriteria dapat diperkecil untuk mengurangi pencurian.

\section{Tenaga Kerja}

Jumlah tenaga kerja umumnya ditentukan berdasarkan estimasi produksi harian yang telah dilakukan. Setiap tenaga kerja ditargetkan kapasitas tertentu yang harus dipenuhi untuk memanen keseluruhan buah agar tidak ada yang tertinggal dan menjadi losses. Kapasitas yang ditentukan afdeling IV kepada setiap pemanen rata-rata sebesar $1,040 \mathrm{~kg}$ maka jumlah tenaga kerja realisasi yang digunakan berdasarkan kerapatan panen dapat dilihat pada Tabel 3.

Tabel 3. Penggunaan tenaga kerja harian

\begin{tabular}{|c|c|c|c|}
\hline \multirow[b]{2}{*}{ Tanggal } & \multirow{2}{*}{$\begin{array}{l}\text { Estimasi Produksi } \\
\text { Harian }(\mathrm{kg})\end{array}$} & \multicolumn{2}{|c|}{$\begin{array}{l}\text { Jumlah Tenaga } \\
\text { Kerja }\end{array}$} \\
\hline & & $\begin{array}{l}\text { Rencana } \\
\text { (SOP) }\end{array}$ & Realisasi \\
\hline $02 / 05 / 18$ & 25459 & 25 & 40 \\
\hline 03/05/18 & 27137 & 26 & 32 \\
\hline $04 / 05 / 18$ & 27372 & 27 & 33 \\
\hline $05 / 05 / 18$ & 27772 & 27 & 41 \\
\hline $06 / 06 / 18$ & 37170 & 36 & 40 \\
\hline Rata-rata & & $28.2 b$ & $37.2 \mathrm{a}$ \\
\hline
\end{tabular}

Keterangan: Angka pada baris yang sama diikuti huruf yang berbeda menunjukkan beda nyata pada taraf $\alpha=$ $5 \%$.

Berdasarkan data pada Tabel 3 menunjukkan jumlah tenaga kerja yang dibutuhkan tidak dihitung berdasarkan hasil 
perhitungan AKP. Jumlah tenaga kerja realisasi berbeda nyata dengan rencana kerja.

Hal ini terjadi karena kerapatan panen yang rendah pada satu kapveld sehingga untuk menyesuaikan target produksi harian maka harus menambah tenaga kerja dan blok pada kapveld lain. Jumlah pemanen tidak dikurangi karena apabila tenaga kerja sedikit dan menggunakan hanca tetap maka akan memperluas hanca setiap pemanen sehingga menyebabkan resiko hanca ditinggal akan semakin besar. Jika dilihat dari jumlah pemanen yang merupakan karyawan tetap hanya sebanyak 17 orang maka saat ini dilakukan perekrutan khusus pemanen. Seluruh pemanen yang mengikuti tergolong sebagai calon karyawan yang harus memenuhi SPO perusahaan sehingga mutu harus dijaga. Total pemanen bertambah menjadi 43 orang yang mengakibatkan rotasi panen menjadi lebih pendek.

\section{Hanca Panen}

Hanca adalah areal yang menjadi tanggung jawab setiap pemanen saat panen berlangsung. Sistem hanca yang diterapkan pada bulan Mei dan Juni di afdeling IV Kebun Adolina adalah hanca giring. Hanca giring adalah hanca yang diberikan secara bertahap pada luasan areal tertentu sehingga pemanen tidak langsung menetap pada areal dan areal akan berbeda saat memasuki kapveld yang sama. Setiap hari pemanen berkumpul untuk mengikuti gotong royong dan kumpulan pagi pada pukul 06.00-07.00 WIB. Kemudian mandor panen memberikan hanca kepada pemanen seluas 2 lorong untuk dipanen terlebih dahulu. Apabila telah selesai, hanca ditambah hingga pemanen berpindah sebanyak 34 kali. Awalnya sistem hanca yang diterapkan pada bulan Januari hingga April adalah hanca tetap sebanyak 4-6 lorong. Kemudian diubah saat ditemukan banyaknya losses pada pemeriksaan mutu hanca secara bertahap yaitu buah matang tinggal di pokok dan buah dipanen sudah menuju tandan kosong. Penyebabnya adalah pemanen sering meninggalkan sebagian areal yang rawan pencurian. Pemanen berasumsi kalau buah yang berada di hanca rawan tersebut sudah kosong Berdasarkan penemuan losses tersebut maka sistem hanca diubah menjadi hanca giring.

Sistem hanca memiliki kelebihan dan kekurangan dalam proses panen. Berdasarkan pengamatan dilapang, sistem hanca giring memiliki kelebihan dalam hal pengawasan karena pemanenan fokus pada areal yang lebih kecil. Kelebihan lain bila dilihat dari losses buah tinggal dan buah menuju tandan kosong menunjukkan kondisi sangat baik. Selain itu sistem ini juga mempermudah proses pengangkutan TBS. Truk memungkinkan mengangkut TBS sekaligus pada suatu areal karena keseluruhan TBS sudah berada di TPH. Kekurangan hanca giring terletak pada tanggung jawab pemanen yang rendah. Kekurangan lainnya yaitu kegiatan sortasi yang dilakukan P2B menjadi lebih sulit dan tidak optimal. Hal ini disebabkan setiap kemandoran memiliki P2B masing-masing, namun pembagian hanca pemanen dari 2 kemandoran digabungkan pada areal tersebut.

\section{Pelaksanaan Panen}

Pelaksanaan panen adalah kondisi saat berlangsungnya kegiatan panen. Hal-hal yang harus diperhatikan saat pelaksanaan panen adalah perlengkapan panen, kriteria matang panen, teknis panen dan pengangkutan hasil.

\section{Kriteria Matang Panen}

Kriteria matang panen adalah kondisi tandan buah segar yang boleh dipanen berdasarkan syarat dari perusahaan. Buah yang boleh dipanen pada tanaman remaja ( $\leq 10$ tahun) yaitu saat ditemukan 5 brondolan pertandan berada dipiringan. Berbeda dengan tanaman tua (> 10 tahun) yang boleh dipanen yaitu saat ditemukan 9 brondolan. Brondolan yang dimaksudkan adalah brondolan segar dan normal, sedangkan brondolan kering atau sakit tidak dapat dijadikan kriteria. Apabila pemanen tidak menemukan kriteria tersebut maka buah tidak diperbolehkan untuk dipotong. Penetapan kriteria matang panen bertujuan untuk mendapatkan rendemen yang cukup tinggi, brondolan tidak terlalu banyak dan jumlah pelepah dapat diatur secara ideal sekitar 48-56 (PTPN IV, 2007). Kriteria matang panen dapat dilihat pada Tabel 4.

Tabel 4. Kriteria matang panen Kebun Adolina

\begin{tabular}{lcl}
\hline Tingkat Kematangan & Fraksi & Kriteria \\
\hline Sangat mentah & F00 & $\begin{array}{l}\text { Belum } \\
\text { membrondol } \\
\text { Mentah }\end{array}$ \\
Matang normal & - & $\begin{array}{l}\text { Membrondol 1-4 } \\
\text { Fembrondol } \geq 5\end{array}$ \\
Tandan kosong & & $\begin{array}{l}\text { Buah luar telah } \\
\text { membrondol } \\
\text { semua }\end{array}$ \\
\hline
\end{tabular}

Sumber : Kantor Besar Kebun Adolina

Kualitas TBS tidak dapat ditentukan hanya berdasarkan hasil sortir pada mutu TPH. Melainkan perlu diperhatikan juga kondisi brondolan setiap TBS yang hendak dipotong untuk memastikan pelaksanaan standar oleh pemanen. Terdapat perbedaan kriteria matang panen dari buah yang dipotong saat tanggal tertentu pada bulan Mei. Hasil potongan berdasarkan jumlah brondolan dapat dilihat pada Tabel 5. 
Tabel 5. Kriteria matang panen berdasarkan potongan pemanen

\begin{tabular}{|c|c|c|c|c|c|c|}
\hline \multirow{3}{*}{$\begin{array}{l}\text { No. } \\
\text { Pemanen }\end{array}$} & \multicolumn{6}{|c|}{ Jumlah Brondolan (butir) / Tanggal } \\
\hline & \multicolumn{4}{|c|}{$10-15$} & \multicolumn{2}{|c|}{$25-30$} \\
\hline & Normal & $\mathrm{F} 0$ & $\mathrm{~F} 00$ & Normal & F0 & $\mathrm{F} 00$ \\
\hline 34 & 8 & 2 & 0 & 5 & 4 & 1 \\
\hline 29 & 7 & 3 & 0 & 4 & 5 & 1 \\
\hline 36 & 8 & 2 & 0 & 6 & 2 & 2 \\
\hline 44 & 8 & 2 & 0 & 5 & 4 & 1 \\
\hline 47 & 6 & 4 & 0 & 4 & 6 & 1 \\
\hline 45 & 8 & 2 & 0 & 5 & 5 & 0 \\
\hline Rata-rata & 7.5 & 2.5 & 0 & 4.8 & 4.3 & 1 \\
\hline
\end{tabular}

Berbagai upaya dilakukan untuk mencapai target produksi setiap bulan. Terutama dalam hal mencapai target harian melalui peningkatan jumlah dan kapasitas dari pemanen per hari. Berdasarkan data pada Tabel 5 menunjukkan kriteria matang panen pada tanggal 10-15 masih lebih diperhatikan pemanen dari pada tanggal 2530. Pengamatan yang dilakukan menunjukkan saat tanggal 25-30, pemanen dituntut mendapatkan kapasitas yang lebih besar sehingga pemanen menghiraukan kriteria matang panen dan resiko buah mentah menjadi meningkat.

\section{Pengangkutan Tandan Buah Segar (TBS)}

Pengangkutan TBS memiliki peranan penting dalam menjaga kualitas minyak yang telah dipanen. Buah yang tidak segera diangkut akan menyebabkan kerugian seperti kenaikan asam lemak bebas (ALB) dan meningkatnya resiko kehilangan yang disebabkan pencurian TBS di TPH (Lubis, 2011). Pengangkutan di Afdeling IV menggunakan kendaraan pemborong sebanyak 3 truk yang selalu tersedia. Penentuan jumlah truk tidak didasari kerapatan buah pada kapveld tersebut, melainkan target harian yang telah dibagi dari penyebaran RKAP bulanan. Seharusnya jumlah truk ditentukan berdasarkan kerapatan buah karena tiap bulan jumlah truk yang dibutuhkan akan berbeda akibat produksi tiap bulan yang berbeda (Hudori, 2016). Truk tersebut hanya digunakan untuk mengangkut hasil panen dan tidak digunakan untuk kegiatan lain.
Waktu yang dibutuhkan untuk menyelesaikan muatan per trip dapat dilihat pada Tabel 6 .

Berdasarkan data pada Tabel 6 pengangkutan membutuhkan waktu \pm 3.5 jam. Hal ini sudah sesuai karena setiap ulangan tidak menunjukkan perbedaan secara signifikan. Penulis mengamati jumlah trip dari bulan Februari sampai Mei sebanyak 6-7 trip, apabila muatan/truk sebesar 8 ton maka setiap truk hanya mengangkut 2-3 trip. Pengangkutan mulai dilakukan jam 10.00 WIB dan dapat diselesaikan 20.30 WIB. Kondisi yang harus dipertimbangkan kembali yaitu bulan bulan Juni dan seterusnya, ketika target meningkat dan mengakibatkan truk harus mengangkut 3-4 trip. Kondisi ini menyebabkan pekerjaan selesai melewati jam 24.00 WIB atau bahkan melewati saat truk tidak dalam keadaan baik. Kondisi ini akan meningkatkan resiko kehilangan TBS di TPH dan kenaikan ALB akibat buah rentan (Purwanto dan Santosa, 2016). Menurut Sibuea (2014) ALB akan terus meningkat sebesar $0.9-1.0 \%$ setiap 24 jam jika tidak langsung diolah.

Data tersebut juga menunjukkan waktu paling banyak diperlukan pada kegiatan muat (loading). Hal ini disebabkan penyusunan TBS keatas truk harus dibentuk petak agar muatan truk menjadi lebih banyak. Selain proses pemetakan, proses muat keatas truk juga membutuhkan waktu lebih karena sebagian besar blok memiliki TPH yang dibatasi parit dari jalur truk. Akibatnya pemuat harus melewati jembatan sepanjang 3-5 meter untuk memuat TBS. Perbedaan waktu muat antara penggunaan jembatan dan tidak dapat dilihat pada Tabel 7.

Berdasarkan data pada Tabel 7, waktu ratarata yang digunakan untuk mengangkut per TBS dari tiap TPH menunjukkan perbedaan secara nyata antara pemuat yang melewati jembatan dan tidak. Hal ini disebabkan penggunaan jembatan menyebabkan pemuat harus bergantian dan saling menunggu untuk mengambil buah atau cara lain yang dilakukan pemuat adalah melempar buah ke sekitar truk terlebih dahulu kemudian dimuat kedalam truk.

Tabel 6. Waktu muat dan bongkar

\begin{tabular}{|c|c|c|c|c|c|c|}
\hline Ulangan & $\begin{array}{l}\text { Waktu muat } \\
\text { (menit) }\end{array}$ & $\begin{array}{l}\text { Waktu berangkat } \\
\text { (menit) }\end{array}$ & $\begin{array}{l}\text { Waktu bongkar } \\
\text { (menit) }\end{array}$ & $\begin{array}{l}\text { Waktu pulang } \\
\text { (menit) }\end{array}$ & $\begin{array}{l}\text { Waktu per trip } \\
\text { (menit) }\end{array}$ & $\begin{array}{l}\text { Berat TBS } \\
\quad(\mathrm{kg})\end{array}$ \\
\hline 1 & 76 & 53 & 35 & 43 & 206 & 7930 \\
\hline 2 & 85 & 57 & 39 & 43 & 224 & 8187 \\
\hline 3 & 76 & 57 & 30 & 40 & 203 & 7437 \\
\hline Rata-rata & 79 & 56 & 34 & 42 & 211 & 7851 \\
\hline \multirow{2}{*}{ Tabel } & \multirow{2}{*}{$\begin{array}{l}\text { Perbedaan waktu } \\
\text { penggunaan jembatan }\end{array}$} & \multirow{2}{*}{ berdasarkan } & Jemba & Jembata & & \\
\hline & & & 2.1 & 4.7 & & \\
\hline \multicolumn{2}{|c|}{ Rataan waktu/buah (detik) } & \multirow[b]{2}{*}{ P-Value } & 3.0 & 4.3 & & \\
\hline Tanpa & Dengan & & 2.1 & 4.7 & & \\
\hline
\end{tabular}




$\begin{array}{lll}1.8 & 4.4 & <0.0001^{* *} \\ 2.1 & 4.5 & \\ 2.1 & 4.1 & \\ 1.8 & 3.7 & \\ 2.2 & 5.7 & \end{array}$

Keterangan : $(* *)=$ berbeda sangat nyata pada $\operatorname{taraf} \alpha=$ $1 \%$.

Akibatnya waktu akan terbuang dan TBS juga mengalami benturan lebih keras dibandingkan proses muat tanpa jembatan. TBS yang dilemparkan ke jalan atau ke truk dari tengah jembatan akan menyebabkan resiko memar lebih besar dibandingkan biasanya. TBS memar seluruhnya memiliki kadar ALB 9.95\%, sedangkan $20 \%$ memar dan $80 \%$ utuh memiliki kadar ALB sebesar 2.82\% (Krisdiarto, 2017).

\section{Pengawasan dan Evaluasi}

Pengawasan dan evaluasi adalah kegiatan yang dilakukan setelah proses panen selesai dilaksanakan. Kegiatan ini merupakan langkah untuk mempertahankan secara konsisten kualitas dan kuantitas panen yang sedang dan akan berlangsung. Hal-hal yang harus dilakukan adalah pengawasan mutu, denda dan sanksi panen, kapasitas pemanen, basis dan premi panen serta losses panen akibat pencurian.

\section{Pengawasan Mutu}

Mutu buah sesuai kriteria matang panen harus dipertahankan secara konsisten melalui pengawasan bertingkat kepada pemanen. Saat Tabel 8. Tingkat kesalahan pemanen pada hanca

\begin{tabular}{|c|c|c|c|c|c|c|c|}
\hline \multirow{2}{*}{ Ulangan } & \multicolumn{2}{|c|}{ Buah } & \multicolumn{2}{|c|}{ Brondolan } & \multicolumn{3}{|c|}{ Pelepah } \\
\hline & MT & DTD & DP & DB & $\mathrm{S}$ & TD & TS \\
\hline 1 & 0 & 0 & 5.0 & 3.4 & 0.4 & 3.0 & 0 \\
\hline 2 & 0 & 0 & 8.6 & 6.0 & 0.2 & 2.6 & 1.0 \\
\hline 3 & 0 & 0 & 14 & 3.6 & 0.2 & 3.6 & 0.8 \\
\hline Rata-rata & 0 & 0 & 9.2 & 4.3 & 0.3 & 3.1 & 0.6 \\
\hline
\end{tabular}

Keterangan : MT: Matang tidak dipanen, DTD: Dipanen tertinggal dipiringan, DP: Dipiringan, DB: Dipasar pikul+bonggol, S: Sengkleh, TD: Tidak dipotong, TS: Tidak disusun.

Tabel 9. Tingkat kesalahan pemanen pada TPH

\begin{tabular}{|c|c|c|c|c|c|c|c|c|c|c|}
\hline \multirow{2}{*}{ Ulangan } & \multirow{2}{*}{$\begin{array}{l}\text { Jumlah } \\
\text { tandan }\end{array}$} & \multicolumn{5}{|c|}{ Kematangan buah } & \multicolumn{4}{|c|}{ Potongan tandan } \\
\hline & & F00 & F0 & $\mathrm{N}$ & F5 & $\% \mathrm{~N}$ & V & $\mathrm{N}$ & $\mathrm{P}$ & $\% \mathrm{P}$ \\
\hline 1 & 173 & 6 & 9 & 158 & 0 & 91.3 & 34 & 139 & 0 & 0 \\
\hline 2 & 150 & 1 & 4 & 145 & 0 & 96.7 & 27 & 123 & 0 & 0 \\
\hline 3 & 446 & 5 & 26 & 415 & 0 & 93.0 & 19 & 425 & 2 & 0.44 \\
\hline
\end{tabular}

Keterangan : F00: Sangat mentah, F0: Mentah, F5: Tandan kosong, V: Potongan tandan berbentuk huruf V.

Potongan tandan panjang sudah sangat minimal, namun harus terus ditingkatkan agar potongan normal menjadi sesuai SPO berbentuk V. prestasi pemanen tinggi dan mutu buah baik maka setiap tingkatan mendapatkan premi serta insentif tertentu. Sebaliknya ketika ditemukan kesalahan pada mutu TPH dan mutu hanca maka diberlakukan denda dan sanksi. Hasil pengawasan mutu hanca dan TPH dapat dilihat pada Tabel 8 dan 9 .

Secara umum data pada Tabel 8 dan 9 menunjukkan kesalahan pada ulangan ke 3 lebih besar dibandingkan ulangan 1 dan 2 . Hal ini disebabkan ulangan ke 3 diamati pada pertengahan bulan Juli saat target bulanan tinggi dan hari kerja berkurang karena banyaknya hari libur. Kondisi tersebut mengakibatkan pemanen diberi tekanan untuk mendapatkan hasil lebih sehingga menghiraukan aturan. Berdasarkan data pada Tabel 8 menunjukkan tidak ditemukannya buah matang dan buah menuju tandan kosong tidak dipanen setelah hanca giring diterapkan. Hanca giring tetap memberikan hasil terbaik karena tidak ditemukannya buah matang tidak dipanen (Anugrah, 2017).

Data tersebut juga menunjukkan jumlah buah mentah meningkat pada setiap ulangan kecuali ulangan ke 2 . Hal ini disebabkan rotasi potong buah yang mencapai 3 hari. Khusus ulangan ke 2 pemanen ditegaskan untuk tidak memotong buah mentah. Menurut Pahan (2008) pusingan yang terlalu cepat akan mendorong pemanen untuk memotong buah mentah karena harus mengejar siap borong disaat angka kerapatan buah menurun.

Menurut Sibuea (2014) tandan panjang pada TBS dapat menghisap banyak minyak, kotoran, sampah yang dapat menurunkan mutu minyak. Kesalahan pemanenan juga perlu diperhatikan 
pada hanca yang memiliki pola tanam big hole dengan ukuran $3 \mathrm{~m} \times 3 \mathrm{~m} \times 1 \mathrm{~m}$. Hasil pengamatan berdasarkan pola tanam dapat dilihat pada Tabel 10.

Tabel 10. Perbedaan tingkat kesalahan pemanen berdasarkan pola tanam

\begin{tabular}{lcccccc}
\hline & \multicolumn{3}{c}{ Brondolan } & \multicolumn{2}{c}{ Pelepah } & \multicolumn{2}{c}{ P-Value } \\
\cline { 2 - 7 } Pemanen & BT & BT & PP & PP & BT(S) & BT(S) \\
& (S) & (B) & (S1) & (B1) & BT(B) & BT(B) \\
\hline 1 & 6 & 51 & 6 & 0 & & \\
2 & 7 & 53 & 6 & 0 & & \\
3 & 8 & 67 & 8 & 6 & & \\
4 & 16 & 56 & 2 & 0 & & \\
5 & 14 & 34 & 7 & 0 & & \\
6 & & & & & $<0.000$ & $<0.000$ \\
7 & 9 & 28 & 8 & 0 & $1 * *$ & $1 * *$ \\
8 & 5 & 31 & 9 & 1 & & \\
9 & 7 & 42 & 8 & 2 & & \\
10 & 15 & 32 & 7 & 4 & & \\
\hline Rata- & 5 & 41 & 7 & 3 & & \\
\hline
\end{tabular}

$\begin{array}{lllll}\text { Rata-rata } & 9.2 & 43.5 & 6.8 & 1.6\end{array}$

Keterangan : $(* *)=$ berbeda sangat nyata pada taraf $\alpha=$ 1\%, BT: Brondolan tinggal dipiringan, (S): Pola tanam standar,(B): Pola tanam big hole, PP: Pengaturan pelepah (dipotong dan disusun), (S1): umur $\geq 8$ tahun,(B1): umur $\leq 8$ tahun.

Berdasarkan data pada Tabel 10 menunjukkan bahwa losses berupa brondolan tinggal lebih banyak pada pola tanam big hole dibandingkan standar. Hal ini disebabkan pemanen merasa kesulitan bila harus masuk kedalam lubang dan khawatir adanya serangan ular dan kelabang di areal permukaan secara mendadak. Brondolan saat TBS jatuh sering masuk ke celah tanaman, maka pemanen memutuskan untuk menutupnya dengan tanah. Kondisi ini jika dibiarkan akan mengakibatkan kerugian karena brondolan dapat tumbuh menjadi anak sawit (tukulan). Tidak hanya brondolan, pengaturan pelepah juga berbeda antara umur tanaman, pada tanaman umur $\geq 8$ tahun jumlah pelepah yang dipotong lebih ditaati dibandingkan $\leq 8$ tahun. Hal ini disebabkan pemanen menganggap pelepah umur $\leq 8$ tahun tidak

mengganggu jalan panen. Seharusnya pelepah daun dipotong agar proses pelapukan lebih cepat berlangsung.

\section{Kapasitas Pemanen}

Pemanenan merupakan kegiatan menggali produksi yang ada di lapangan. Produksi akan semakin tinggi apabila setiap pemanen mendapatkan kapasitas yang tinggi. Kapasitas adalah hasil yang diperoleh dari seorang pemanen dalam 1 hari kerja dilakukan sendiri atau dibantu kernet selama 7 jam kerja maupun lebih. Kapasitas dapat dilihat dari jumlah buah yang dipanen setiap hari setelah diakumulasikan krani produksi selama satu bulan. Setiap kumpulan pagi, asisten dan mandor memberikan arahan dan target kapasitas yang harus dipenuhi setiap pemanen. Namun sering kali pemanen tidak memenuhi kapasitas yang diharapkan.

Kapasitas ditentukan oleh kemampuan pemanen, penggunaan kernet, serta lama waktu kerja dan waktu istirahat (wolon). Kapasitas antara pemanen yang menggunakan kernet dan kongsi dengan pemanen lainnya menunjukkan beda nyata saat buah dalam kondisi banyak, sedangkan pada kondisi buah sedikit maka hasilnya tidak terlalu beda nyata. Penggunaan kernet dapat menguntungkan bagi perusahaan karena pemanen pasti mendapatkan hasil lebih banyak. Saat pemanenan sistem kongsi kebanyakan pemanen menghabiskan waktu untuk istirahat. Kapasitas pemanen yang menggunakan kernet dan tidak dapat dilihat pada Tabel 11.

Tabel 11. Kapasitas pemanen

\begin{tabular}{lcrl}
\hline & \multicolumn{2}{c}{ Total Hasil kg/HK } & \\
\cline { 2 - 3 } Tanggal & $\begin{array}{c}\text { Pemanen+ } \\
\text { kernet }\end{array}$ & $\begin{array}{r}\text { Pemanen+ } \\
\text { pemanen }\end{array}$ & P-Value \\
\hline 21 & 2402 & 1646.7 & $0.103^{\text {tn }}$ \\
22 & 1590 & 915.0 & $0.070^{\text {tn }}$ \\
23 & 3919 & 1968.0 & $0,003^{*}$ \\
24 & 1715 & 1090.0 & $0.163^{\text {tn }}$ \\
25 & 3680 & 1700.0 & $0.001^{*}$ \\
\hline
\end{tabular}

Keterangan: $(*)=$ berbeda nyata pada taraf $\alpha=5 \%,(\operatorname{tn})$ $=$ tidak berbeda nyata pada taraf $\alpha=5 \%$

\section{Kehilangan Hasil}

Kehilangan hasil merupakan kerugiaan perusahaan yang disebabkan tidak sesuainya mutu panen dan kehilangan akibat pencurian (Pahan, 2008). Tidak sesuainya mutu panen dapat dibenahi melalui kegiatan pengawasan bertingkat dan penerapan sistem denda kepada pemanen. Daftar kehilangan buah akibat pencurian yang terjadi di afdeling IV mulai Januari - Juli 2018 dapat dilihat pada Tabel 12 dan 13.

Tabel 12. Buah yang dapat diselamatkan

\begin{tabular}{|c|c|c|c|c|}
\hline \multirow[b]{2}{*}{ Bulan } & \multicolumn{4}{|c|}{ Diselamatkan } \\
\hline & Frekuensi Kehilangan & Tandan & $\mathrm{kg}$ & $\begin{array}{l}\text { minal (Harga } \\
\text { Rp.1600/kg) }\end{array}$ \\
\hline $\begin{array}{l}\text { Januari } \\
\end{array}$ & 18 & 139 & 2122 & 3395200 \\
\hline
\end{tabular}




\begin{tabular}{|c|c|c|c|c|}
\hline Februari & 20 & 169 & 2545 & 4072000 \\
\hline Maret & 21 & 252 & 3872 & 6195200 \\
\hline April & 28 & 324 & 4428 & 7084800 \\
\hline Mei & 51 & 1054 & 15540 & 24864000 \\
\hline Juni & 23 & 205 & 3066 & 4905600 \\
\hline Total & 161 & 2143 & 31573 & 50516800 \\
\hline
\end{tabular}

Sumber : Kantor Afdeling IV Kebun Adolina

Tabel 13. Buah yang tidak dapat diselamatkan

\begin{tabular}{lcrrr}
\hline & \multicolumn{3}{c}{ Tidak Diselamatkan } \\
\cline { 2 - 5 } Bulan & Frekuensi Kehilangan & Tandan & $\mathrm{kg}$ & $\begin{array}{r}\text { Nominal (Harga } \\
\text { Rp1600/kg) }\end{array}$ \\
\hline Januari & 70 & 1032 & 15522 & 24835200 \\
Februari & 56 & 990 & 13874 & 22198400 \\
Maret & 55 & 926 & 13463 & 21540800 \\
April & 62 & 1060 & 14486 & 23177600 \\
Mei & 74 & 1350 & 19224 & 30758400 \\
Juni & 93 & 7043 & 25237 & 40379200 \\
\hline Total & 410 & & 101806 & 162889600
\end{tabular}

Sumber : Kantor Afdeling IV Kebun Adolina

Data pada Tabel 12 dan 13 menunjukkan afdeling IV memiliki tingkat pencurian yang tinggi. Apabila dibandingkan dengan afdeling lain, kejadian di afdeling IV termasuk tinggi. Mudahnya akses publik termasuk orang sekitar untuk merumput dan sebagainya menyebabkan upaya mengatasi kehilangan membutuhkan pendekatan yang baik. Areal tanaman yang rawan telah dibatasi oleh parit.

Berbagai upaya terus dilakukan afdeling IV untuk meningkatkan jumlah petugas dan memperbaiki strategi pengamanan. Masalah dilapangan terletak pada keadaan parit yang digunakan sebagai pembatas areal kurang dalam dan lebar yang saat ini sudah mengalami erosi sehingga menjadi tidak efektif. Penyelesaian lainnya dapat dilakukan dengan mendalami dan memperluas permukaan parit agar pencuri tidak mudah memasuki areal. Selain itu, perusahaan juga dapat mengajukan ke tenaga pemborong (perusahaan) agar merekrut tenaga provider berasal dari warga sekitar khususnya yang mengetahui kondisi lapangan.

\section{KESIMPULAN}

Kehilangan TBS akibat pencurian menyebabkan kerapatan buah menjadi turun. Dalam rangka mencapai target produksi bulanan, afdeling melakukan penyesuaian menjadi lebih pendek, penambahan jumlah tenaga kerja, perubahan sistem hanca dan penurunan kriteria matang panen pada hanca rawan. Rotasi pendek menyebabkan resiko terpotong buah mentah meningkat dan perubahan sistem menjadi hanca giring menghasilkan losses buah matang tidak panen menjadi tidak ada. Losses berupa brondolan tinggal pada sistem tanam big hole lebih banyak dibandingkan standar. Proses pengangkutan masih membutuhkan evaluasi, karena proses pengangkutan melewati jembatan menyebabkan kerugian seperti waktu yang terbuang dan meningkatkan resiko buah memar. Penggunaan kernet lebih menguntungkan dibandingkan sistem kongsi karena hasilnya akan lebih tinggi terutama pada saat kondisi buah banyak.

\section{UCAPAN TERIMAKASIH}

Ucapan terimakasih disampaikan kepada pimpinan PTPN IV, pimpinan Kebun Adolina dan petugas lapangan yang telah memfasilitasi penelitian ini. Kepada Bapak Kevin Bramantyo yang telah berkenan membimbing di lapangan.

\section{DAFTAR PUSTAKA}

Anarki, G. 2012. Prototipe alat inaktivasi enzim lipase pada buah kelapa sawit (Elaeis guineensis). [Skripsi]. Institut Pertanian Bogor, Bogor.

Anugrah, P.T. 2017. Pengelolaan pemanenan dan transportasi tandan buah segar kelapa sawit (Elaeis guineensis Jacq.) di Bangun Bandar Estate, PT. Socfin Indonesia, Serdang Bedagai, Sumatera Utara. [Skripsi]. Institut Pertanian Bogor, Bogor.

[Ditjenbun] Direktorat Jenderal Perkebunan. 2016. Statistik Perkebunan Indonesia Komoditas Kelapa Sawit 2015-2017. Kementrian Pertanian, Jakarta. 
Hudori, M. 2016. Perencanaan kebutuhan kendaraan angkutan tandan buah segar (TBS) di perkebunan kelapa sawit. Industri Engin 1(5):23-28.

Fauzi, Y., Y.E. Widyastuti., I. Satyawibawa., R.H. Paeru. Kelapa Sawit. Penebar Swadaya, Jakarta.

Krisdiarto A.W., L. Sutiarso, K.H. Widodo. 2017. Optimasi kualitas tandan buah segar kelapa sawit dalam proses panen-angkut menggunakan model dinamis. J. Agritech 1(37) : 101-107.

Lubis, R.E., A. Widanarko. 2011. Buku Pintar Kelapa Sawit. PT AgroMedia Pustaka, Jakarta.

Pahan, I. 2008. Panduan Lengkap Kelapa Sawit : Manajemen Agribisnis dari Hulu hingga Hilir. Penebar Swadaya, Jakarta.

Pardamean, M. 2012. Sukses Membuka Kebun dan Pabrik Kelapa Sawit. Penebar Swadaya, Jakarta.
[PASPI] Palm Oil Agribusiness Strategic Policy Institute. 2017. Mitos dan Fakta Industri Minyak Sawit Indonesia dalam Isu Sosial, Ekonomi dan Lingkungan Global. Gabungan Pengusaha Kelapa Sawit, Bogor.

[PTPN IV] Persero Terbatas Perkebunan Nusantara IV. 2007. Standar Prosedur Operasional (SPO) Tanaman Kelapa Sawit. PTPN IV, Medan.

Purwanto, I.J., E. Santosa. 2016. Hubungan mutu buah dsn curah hujan terhadap kandungan asam lemak bebas pada minyak kelapa sawit. Bul. Agrohorti 4(3): 250-255.

Sibuea, P. 2014. Minyak Kelapa Sawit : Teknologi dan Manfaatnya untuk Pangan Nutrasetikal. Erlangga, Jakarta.

Sipayung, T. 2012. Ekonomi Agribisnis Minyak Sawit. IPB Press, Bogor.

Sulistyo, B., A. Purba., D. Siahaan., J. Efendi., A.Sidik. 2010. Budidaya Kelapa Sawit. PT Balai Pustaka, Jakarta. 